\title{
New data on dracunculoid nematodes from fishes off New Caledonia, including four new species of Philometra (Philometridae) and Ichthyofilaria (Guyanemidae)
}

\author{
František Moravec $^{1}$ and Jean-Lou Justine ${ }^{2}$ \\ ${ }^{1}$ Institute of Parasitology, Biology Centre of the Academy of Sciences of the Czech Republic, Branišovská 31, 37005 České \\ Budějovice, Czech Republic; \\ ${ }^{2}$ Équipe Biogéographie Marine Tropicale, Unité Systématique, Adaptation, Évolution (UPMC, CNRS, MNHN, IRD), Institut de \\ Recherche pour le Développement, BP A5, 98848 Nouméa Cedex, New Caledonia
}

\begin{abstract}
Recent examinations of newly obtained materials of dracunculoid nematodes (Dracunculoidea) parasitizing marine fishes off New Caledonia, South Pacific, revealed the presence of several nematodes of the genera Philometra Costa, 1845 (Philometridae) and Ichthyofilaria Yamaguti, 1935 (Guyanemidae), including the following four new species: Philometra priacanthi sp. n. (males) from the gonads of Priacanthus hamrur (Forsskål) (Priacanthidae), Philometra tenuicauda sp. n. (male and mature and gravid females) from the gonads of Lagocephalus sceleratus (Gmelin) (Tetraodontidae), Philometra dentigubernaculata sp. n. (males) from the oculo-orbit of Tylosurus crocodilus (Péron et Lesueur) (Belonidae), and Ichthyofilaria novaecaledoniensis sp. n. (subgravid female) from the musculature of Hoplichthys citrinus Gilbert (Hoplichthyidae). The new species are characterized mainly by the length and structure of spicules and the gubernaculum, body size, location in the host and by the type of hosts. In addition, the findings of Philometra lethrini Moravec et Justine, 2008 from the gonads of Lethrinus miniatus (Forster) and L. variegatus Valenciennes (both Lethrinidae) represent new host records for this parasite; for the first time, its subgravid females were found to be up to $350 \mathrm{~mm}$ long. The occurrence of Philometra ocularis Moravec, Ogawa, Suzuki, Miyazaki et Donai, 2002 in the oculo-orbit of Epinephelus areolatus (Forsskål) (Serranidae) off New Caledonia was confirmed.
\end{abstract}

Key words: parasitic nematode, Philometra, Ichthyofilaria, marine fish, Lethrinus, Priacanthus, Lagocephalus, Tylosurus, Epinephelus, Hoplichthys, New Caledonia

Although dracunculoid nematodes, in particular the gonad-infecting species of Philometra Costa, 1845 may be severely pathogenic in fish hosts (Sakaguchi et al. 1987, Moravec and Genc 2004, Clarke et al. 2006, Moravec and Salgado-Maldonado 2007, Moravec et al. 2007), the knowledge of the fauna of these parasites in marine fishes of New Caledonian waters remains fragmentary. To date, only two papers (Moravec and Justine 2005, 2008) dealing with philometrids from New Caledonian marine fishes have been published, reporting a total of six Philometra species, P. cyanopodi Moravec et Justine, 2008, P. fasciati Moravec et Justine, 2008, P. lagocephali Moravec et Justine, 2008, P. lethrini Moravec et Justine, 2008, P. ocularis Moravec, Ogawa, Suzuki, Miyazaki et Donai, 2002, and an undescribed gonad-infecting species Philometra sp. from Lutjanus vitta (Quoy et Gaimard).

During 2002-2007, while studying the parasites of marine fishes off New Caledonia, additional samples of dracunculoid nematodes, including three new species of Philometra (Philometridae) and one of Ichthyofilaria
Yamaguti, 1935 (Guyanemidae), were collected from some beloniform, perciform, scorpaeniform and tetraodontiform fishes. Taxonomic evaluation of this material is presented in this paper.

\section{MATERIALS AND METHODS}

Fishes were caught by line or speared, at distances less than $30 \mathrm{~km}$ from Nouméa, New Caledonia, with the exception of the deep-sea species Hoplichthys citrinus Gilbert. All fish specimens were measured, weighed and photographed. A unique number (JNC) was assigned to each fish. The parasitological material was then assigned a corresponding JNC linked to the respective fish host. Dracunculoid nematodes used in this study were recorded from the following species of New Caledonian fishes: Belonidae: hound needlefish, Tylosurus crocodilus (Péron et Lesueur) (1 specimen examined); Hoplichthyidae: lemon ghost flathead, Hoplichthys citrinus (more than 100 specimens examined, see comments under species); Lethrinidae: longspine emperor, Lethrinus genivittatus Valenciennes (20 specimens examined), trumpet emperor, Lethrinus miniatus (Forster) (8) and slender emperor, Lethrinus variegatus Valenciennes (1); Pria- 
canthidae: moontail bullseye, Priacanthus hamrur (Forsskål (8); Serranidae: areolate grouper, Epinephelus areolatus (Forsskål) (3); and Tetraodontidae: silverstripe blaasop, Lagocephalus sceleratus (Gmelin) (8). The nematodes for morphological studies were fixed in hot $4 \%$ formaldehyde solution in physiological saline, or sometimes in hot $70 \%$ ethanol. For light microscopical examination, they were cleared with glycerine. Drawings were made with the aid of a Zeiss microscope drawing attachment. The specimens used for scanning electron microscopy (SEM) were stored in $4 \%$ formaldehyde solution and then postfixed in $1 \%$ osmium tetroxide, dehydrated through a graded acetone series, critical point dried and sputter-coated with platinum; they were examined using a JEOL JSM-7401F scanning electron microscope at an accelerating voltage of $4 \mathrm{kV}$ GB low. All measurements are in micrometres unless otherwise stated. Fish names follow FishBase (Froese and Pauly 2009).

Philometrids often have a high seasonality in reproduction (Moravec 2004), and this is also the case for coral reef fish. In New Caledonia, only two seasons are recognized, hot season (October-May) and cold season (June-September), and the ovaries of fish are often inconspicuous during the cold season. Prevalences of philometrids are different according to the season, and are thus indicated for both seasons. Measurements of fish are indicated for possible future comparison according to the sexual status of the fish.

\section{RESULTS}

Philometridae Baylis et Daubney, 1926

\section{Gonad-infecting species}

Philometra lethrini Moravec et Justine, 2008 Fig. 1

Male (3 specimens from L. variegatus): Length of body $4.83-5.81 \mathrm{~mm}$, maximum width $78-87$. Entire oesophagus $480-543$ long, representing $8-11 \%$ of body length. Nerve ring and cell nucleus of oesophageal gland 96-108 and 330-369, respectively, from anterior extremity. Spicules of about equal length, measuring 108-111 ( $2 \%$ of body length). Gubernaculum 90-93 long, approximately its anterior half somewhat dorsally bent $($ Fig. $1 \mathrm{H})$. Length ratio of gubernaculum and spicules 1:1.19-1.23.

Mature female ( 1 specimen from $L$. variegatus): Body whitish, $3.40 \mathrm{~mm}$ long, maximum width 60 . Cephalic end rounded. Structure of anterior end of body similar to that of male. Entire oesophagus 501 long, representing 15\% of body length. Nerve ring and cell nucleus of oesophageal gland 120 and 342, respectively, from anterior extremity. Uterus poorly developed, empty. Vulva present, being situated $2.30 \mathrm{~mm}$ from anterior extremity (at $68 \%$ of body length); short vagina directed anteriorly from vulva (Fig. 1E). Caudal end broadly rounded (Fig. 1G).

Subgravid female (2 large specimens from L. miniatus; measurements of smaller specimen in parentheses): Body of live specimens red-coloured, that of fixed specimens brownish, with dark brown intestine visible through cuticle. Anterior part of filiform body distinctly broader than posterior. Length of body 350 (90) mm, maximum width 1,061 (612); width of cephalic end 231 (163), that of caudal end 272 (245). Maximum width/body length ratio 1:330 (1:147). Cuticle smooth. Cephalic end rounded, cephalic papillae indistinct in lateral view. Entire oesophagus $1.46(0.95) \mathrm{mm}$ long, without distinct anterior inflation, representing $0.3(1.1) \%$ of body length (Fig. 1A). Oesophageal gland well developed, with large cell nucleus at middle. Maximum width of oesophagus including gland 204 (109). Nerve ring and nucleus of oesophageal gland 367 (258) and 952 (666), respectively, from anterior end of body. Ventriculus small, - (36) long and - (75) wide. Oesophagus opening into intestine through distinct valve. Intestine ending blindly, its posterior end attached by ligament ventrally to body wall near caudal end; length of ligament $1.32(0.61) \mathrm{mm}$. Ovaries long, reflected, situated near body ends. Uterus containing numerous spherical eggs. Caudal end rounded, with two small, poorly visible lateral papilla-like projections (Fig. 1B).

Fourth-stage larva (1 specimen from $L$. variegatus): Body length of specimen undergoing last moulting $1.69 \mathrm{~mm}$, maximum width 45 . Newly formed caudal end broadly oval, still inside moulted cone-shaped larval cuticle (Fig. 1F).

H o s t s : Longspine emperor Lethrinus genivittatus (type host), trumpet emperor L. miniatus, and slender emperor L. variegatus (all Lethrinidae, Perciformes).

Site of infection: Gonads.

L o c a lity: Off Nouméa, New Caledonia, South Pacific.

Prevale n c e : L. genivittatus, 2/20 (10\%) (hot season), in 20 specimens ranging 160-189 mm in length, 16 October 2007. L. variegatus, $1 / 1$ (hot season). L. miniatus, $2 / 5$ for specimens caught during the hot season (JNC1967, 26 September 2006, fork length $440 \mathrm{~mm}$; JNC2113, 7 November 2006, fork length $510 \mathrm{~mm}$ ), 0/3 for specimens caught during the cold season (similar sizes); all specimens of $L$. miniatus were from the outer slope of the barrier reef.

Note about fish: The single specimen of L. variegatus examined (JNC2077, 17 October 2006, off Baie des Citrons, Nouméa, $22^{\circ} 18^{\prime} \mathrm{S}, 166^{\circ} 26^{\prime} \mathrm{E}$ ) was $198 \mathrm{~mm}$ in fork length and thus was very close to the maximum size of the species (200 $\mathrm{mm}$ ); it was a female, although the species is considered a protogynous hermaphrodite (Allsop and West 2003).

Deposition of specimens: Voucher specimens in Muséum National d'Histoire Naturelle, Paris (from L. miniatus, JNC2113D, E; from L. variegatus, JNC2077; from L. genivittatus, JNC2317C, JNC2328).

Remarks. This species has recently been described by Moravec and Justine (2008) from available males and small subgravid females found in the gonads (testes) of the longspine emperor, Lethrinus genivittatus, off $\mathrm{New} \mathrm{Cal}-$ edonia. The newly collected material includes specimens of this species from the type host L. genivittatus ( 3 males, 2 small females about $8 \mathrm{~mm}$ long and 1 subgravid female $115 \mathrm{~mm}$ long), but also from the trumpet emperor L. miniatus (3 large subgravid females up to $350 \mathrm{~mm}$ long) and the slender emperor L. variegatus (5 males, 1 subgravid 

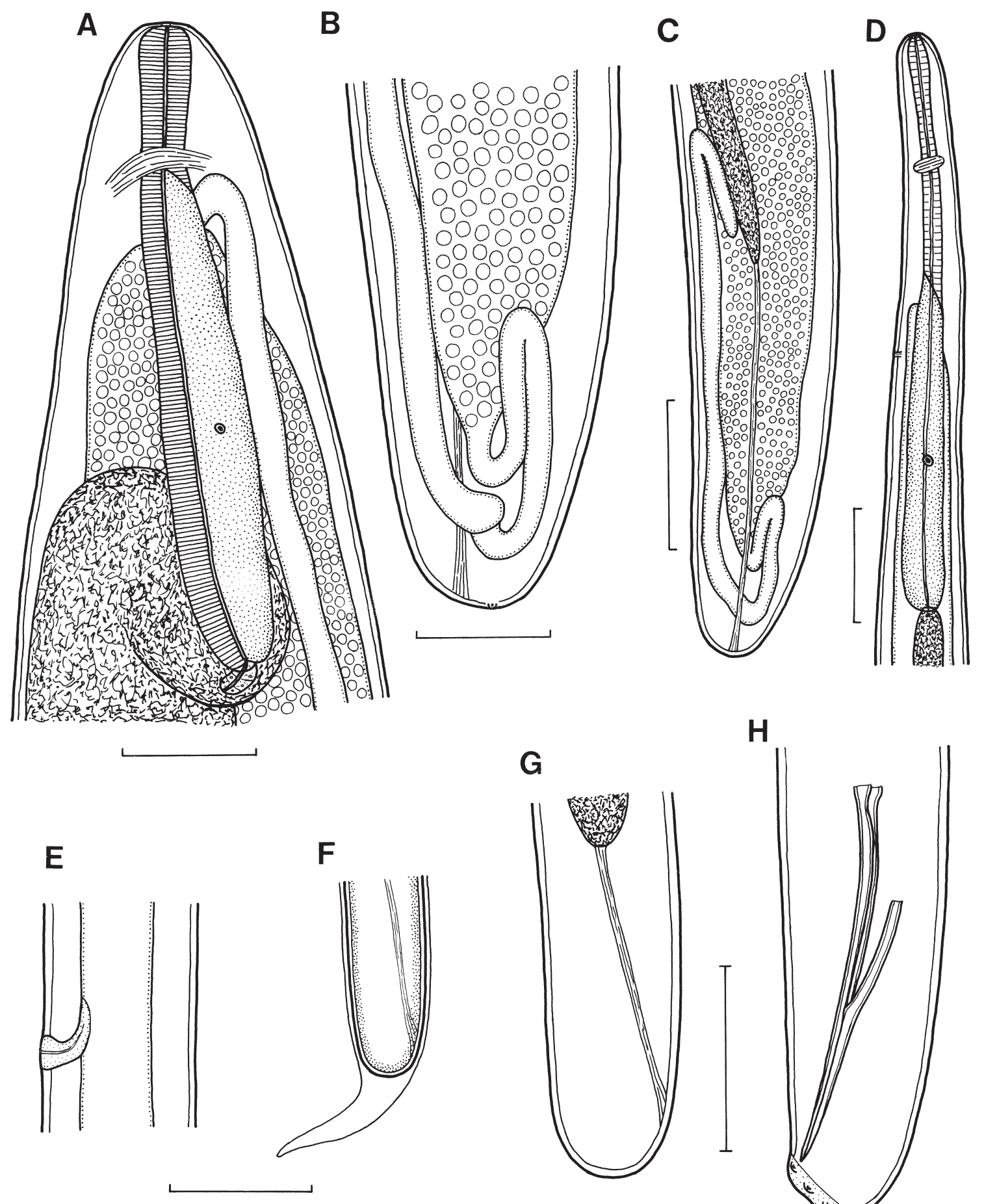

H

$E$

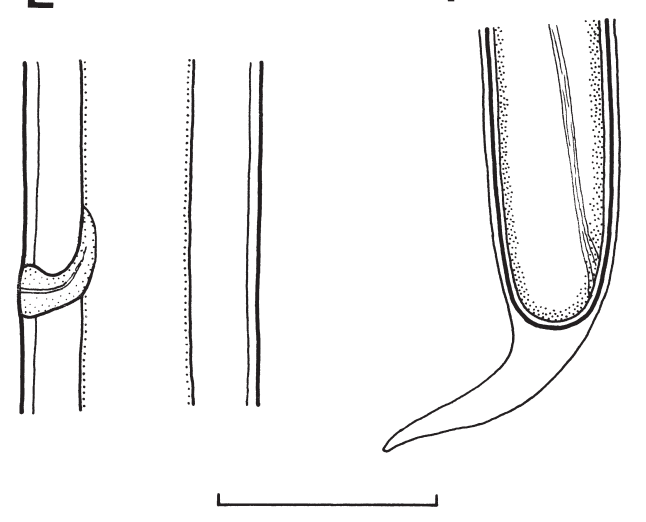

$H_{1}$

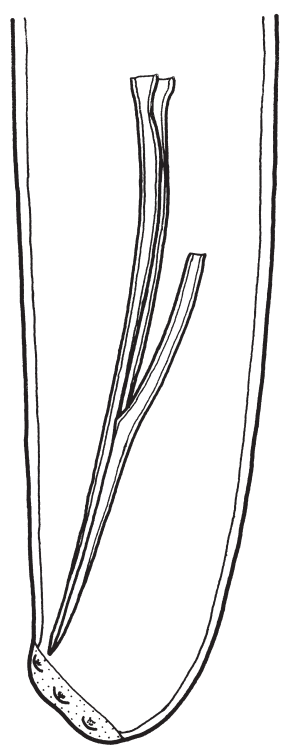

Fig. 1. Philometra lethrini Moravec et Justine, 2008. A, B - anterior and posterior ends of largest subgravid female, lateral views; $\mathbf{C}$ - posterior end of female, lateral view (lower magnification); D - anterior end of male, lateral view; $\mathbf{E}$ - region of vulva in mature female, lateral view; $\mathbf{F}$ - caudal end of moulting fourth-stage larva; $\mathbf{G}$ - caudal end of mature female, lateral view; $\mathbf{H}$ - caudal end of male, lateral view. (A-C - from Lethrinus miniatus; D-H - from L. variegatus.) Scale bars: A, B $=300 \mu \mathrm{m} ; \mathrm{C}=500 \mu \mathrm{m}$; $\mathrm{D}=100 \mu \mathrm{m} ; \mathrm{E}-\mathrm{H}=50 \mu \mathrm{m}$. 
A

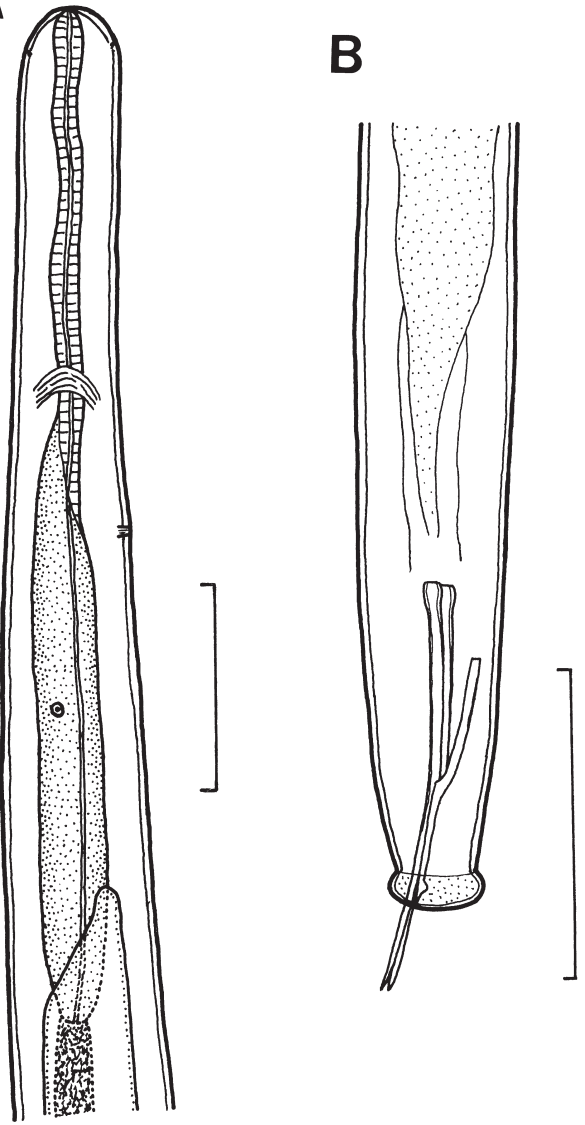

C

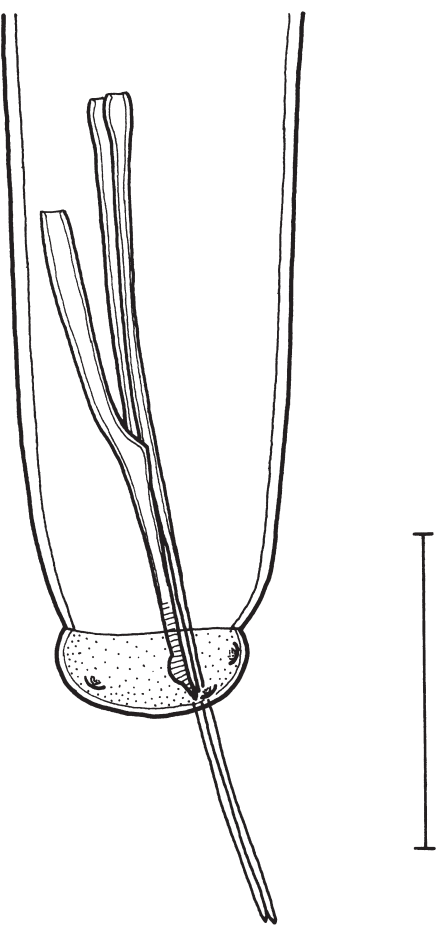

D

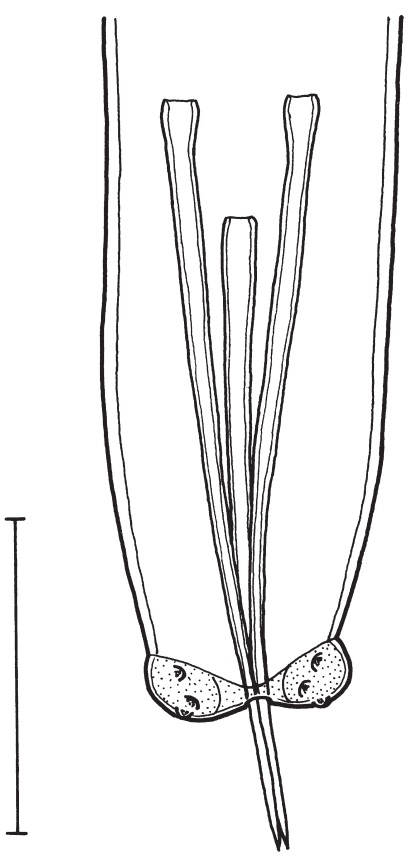

Fig. 2. Philometra priacanthi sp. n., male. A - anterior end, lateral view; $\mathbf{B}$ - posterior end, lateral view; C, D - caudal end, lateral and ventral views. Scale bars: $A=60 \mu \mathrm{m} ; \mathrm{B}=100 \mu \mathrm{m} ; \mathrm{C}, \mathrm{D}=50 \mu \mathrm{m}$.

female $8.3 \mathrm{~mm}$ long, 1 mature female and 1 moulting fourth-stage larva). The last two hosts represent new host records for this nematode species.

Even though no males of $P$. lethrini were found in L. miniatus, the species identification is based on the general female morphology of specimens of the present material, a relatively high degree of host specificity in philometrids (Moravec 2006) and the fact that these nematodes come from the congeneric host in the same locality.

In contrast to the original description of $P$. lethrini, where the maximum body length of available subgravid females was $41 \mathrm{~mm}$, the females from L. miniatus are much more advanced, attaining the length up to $350 \mathrm{~mm}$; it can be expected that $P$. lethrini gravid females with larvae are even longer. The body length of gravid females is an important taxonomic feature in philometrids (Moravec 2006). As indicated by the present material, large females of $P$. lethrini are characterized by the absence of a distinct inflation of the anterior end of the oesophagus, which is typical of the great majority of philometrid species. By this feature, P. lethrini is similar to only a few Philometra species parasitizing gonads of marine fishes, such as P. filiformis (Stossich, 1896) or P. justinei Moravec, Ternengo et Levron, 2006.
Philometra priacanthi sp. $\mathrm{n}$.

Figs. 2, 3

Male (5 specimens; measurements of holotype in parentheses): Body filiform, whitish, 3.01-3.60 (3.26) mm long, maximum width at middle 60-72 (60), somewhat tapering at both ends. Cuticle smooth. Cephalic end rounded. Oral aperture circular, very small, surrounded by 14 minute cephalic papillae arranged in two circles: external circle formed by 4 submedian pairs of papillae, internal circle by 4 submedian and 2 lateral papillae; amphids slightly outlined (Fig. 3A). Oesophagus 306-426 (336) long, forming 9-14 (10)\% of body length, slightly inflated at anterior end; posterior part of muscular oesophagus overlapped by well-developed oesophageal gland with large cell nucleus in middle (Fig. 2A). Oesophageal nucleus and nerve ring 231-297 (246) and 102-126 (111), respectively, from anterior extremity. Excretory pore located somewhat posterior to nerve ring. Testis slightly exceeding anteriorly posterior end of oesophagus. Posterior end of body blunt, with two broad lateral U-shaped mounds dorsally distinctly separated from each other (Fig. 3B); 3 pairs (1 preanal, 1 adanal and 1 postanal) of flat, hardly visible caudal papillae present (Fig. 2C, D). Spicules slender, needle-like, with somewhat expanded proximal and sharply pointed distal ends (Fig. 2B-D); 
right spicule slightly longer than left spicule or both spicules equal in length. Length of right spicule 132-153 (132), of left spicule 129-153 (129); length ratio of spicules $1: 1.00-1.02(1: 1.02)$; length of right spicule representing 4.04-4.49 (4.49)\% of body length. Gubernaculum narrow, 66-93 (87) long, with approximately its proximal half somewhat dorsally bent; length of anterior bent part 39-54 (42), representing 48-59 (48)\% of entire gubernaculum length; distal part of gubernaculum with remarkable transverse lamella-like structure on dorsal side (Fig. 3C) forming distinct dorsal protuberance at short distance from gubernaculum end (Fig. 2C). Length ratio of gubernaculum and right spicule 1:1.42-2.14 (1:1.52). Spicules and gubernaculum well sclerotized; spicules and posterior part of gubernaculum orange-coloured, anterior part of gubernaculum colourless.

Female: Unknown

Type host: Moontail bullseye, Priacanthus hamrur (Priacanthidae, Perciformes).

Site of infection: Gonads.

Type locality: Off Nouméa, New Caledonia, South Pacific.

Prevalence and intensity: 2/2 in specimens collected in March 2007 (hot season), 0/6 in specimens collected in September 2004, May 2005, June and July 2007 (cold season); gonads are inconspicuous during the cold season.

Deposition of type specimens: Holotype and 10 paratypes in Muséum National d'Histoire Naturelle, Paris (JNC 2156); 5 paratypes in Institute of Parasitology, Biology Centre, ASCR, České Budějovice (N-634).

Etymology: The specific name of this new species is derived from the generic name of its fish host.

Remarks. According to Moravec et al. (2009), at present there are 27 gonad-infecting species of Philometra parasitizing marine and brackish-water fishes that can be considered valid. Only eight of them, P. charlestonensis Moravec, de Buron, Baker et González-Solís, 2008, P. cyanopodi Moravec et Justine, 2008, P. lateolabracis (Yamaguti, 1935), P. madai Quiazon, Yoshinaga et Ogawa, 2008, P. nemipteri Luo, 2001, P. saltatrix Ramachandran, 1973, P. sarawa Quiazon, Yoshinaga et Ogawa, 2008 and P. sciaenae Yamaguti, 1941, were described to possess marked dorsal lamella-like structures on the distal part of the gubernaculum (Moravec and Justine 2008, Moravec et al. 2008a,b, Quiazon et al. $2008 \mathrm{a}, \mathrm{b})$, which are also characteristic of $P$. priacanthi sp. n. However, the only species with a distinct dorsal protuberance near the gubernaculum end, typical also of $P$. priacanthi, is $P$. lateolabracis (see Quiazon et al. 2008a). The latter species can be differentiated from the former by the lateral caudal mounds broadly separated from each other dorsally, narrower lamella-like structures on the gubernaculum, mostly shorter spicules (65-130 vs. 129-153), and by the testis extending anteriorly far anterior to oesophageal cell nucleus. Other gonad-infecting
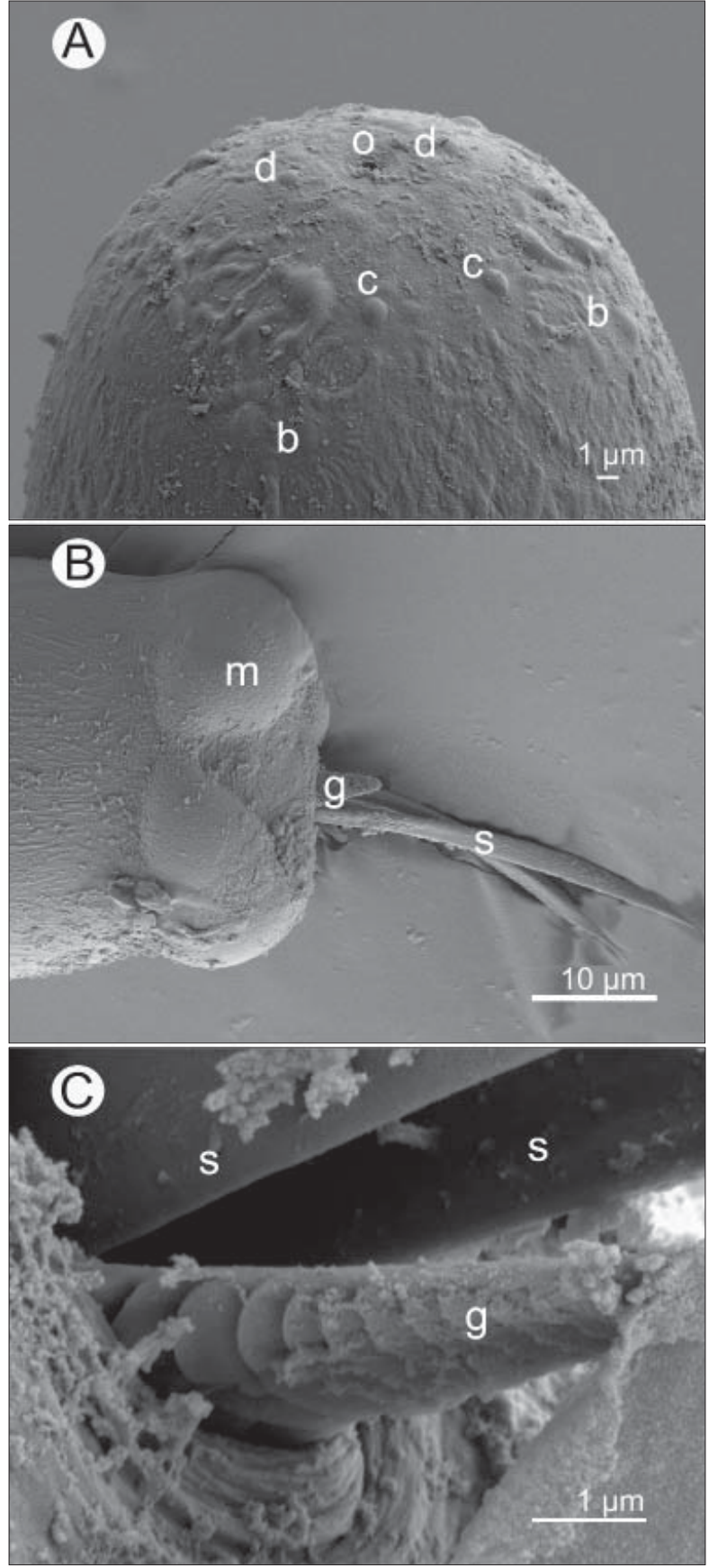

Fig. 3. Philometra priacanthi sp. n., scanning electron micrographs of male. A - cephalic end, sublateral view; $\mathbf{B}$ - caudal end, dorsal view; $\mathbf{C}$ - region of cloacal opening with extruded distal end of gubernaculum, sublateral view. Abbreviations: $\mathrm{b}$ - pair of submedian cephalic papillae of external circle; c submedian cephalic papilla of internal circle; $d$ - lateral cephalic papilla of internal circle; $\mathrm{o}$ - oral aperture; $\mathrm{g}$ - distal end of gubernaculum; $\mathrm{m}$ - caudal U-shaped mound; $\mathrm{s}$ - extruded spicule.

species differ from $P$. priacanthi in having a smooth gubernaculum, sometimes provided with a conspicuous, reflected dorsal barb on the distal tip, and their spicules are usually distinctly longer or shorter. 

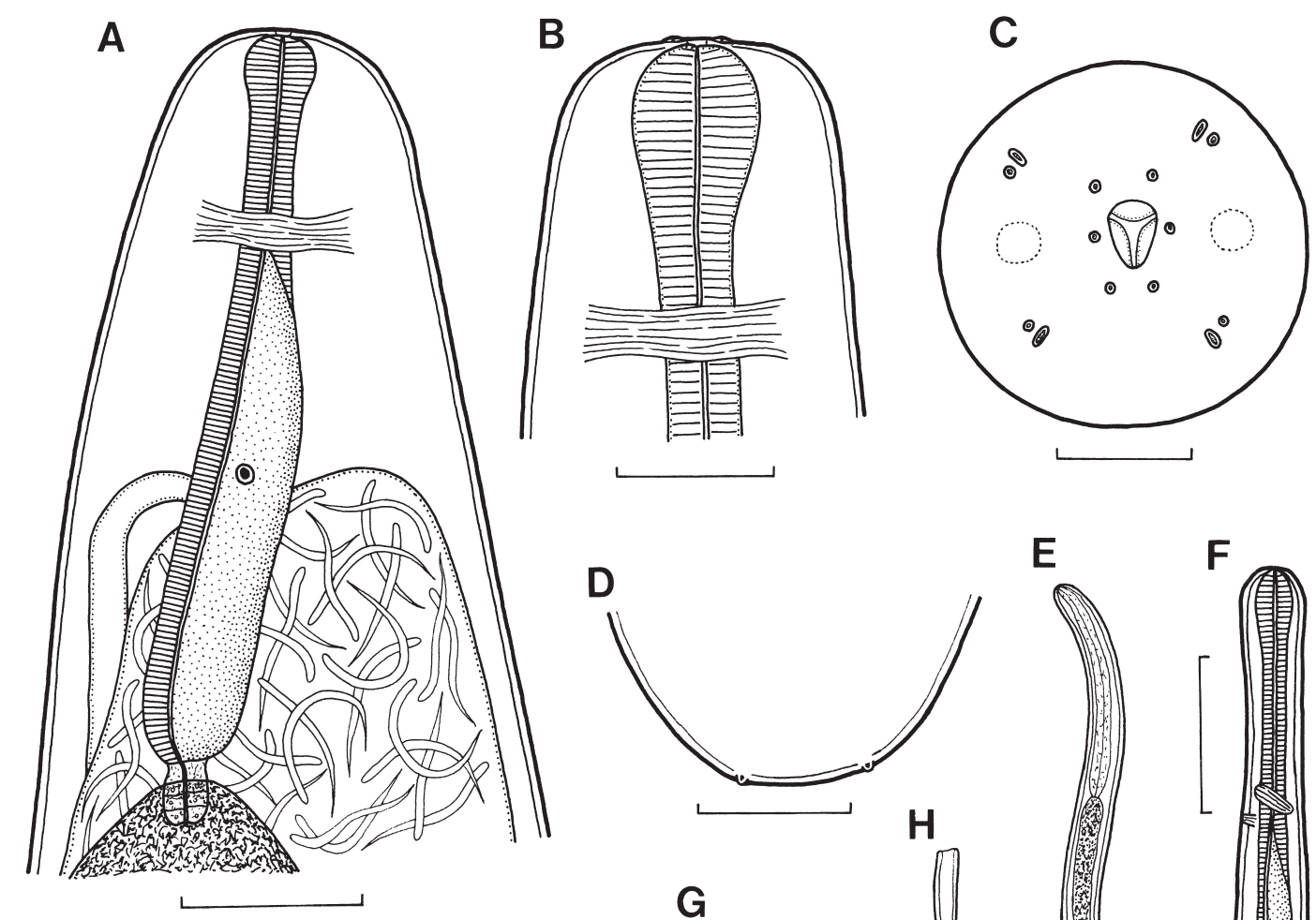

E

$\mathbf{F}$

I

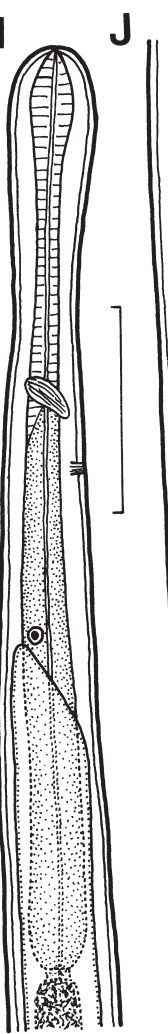

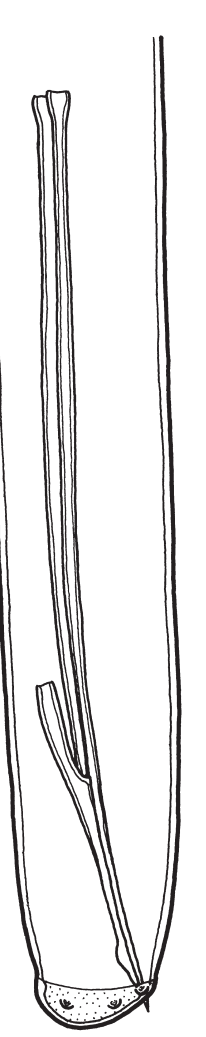
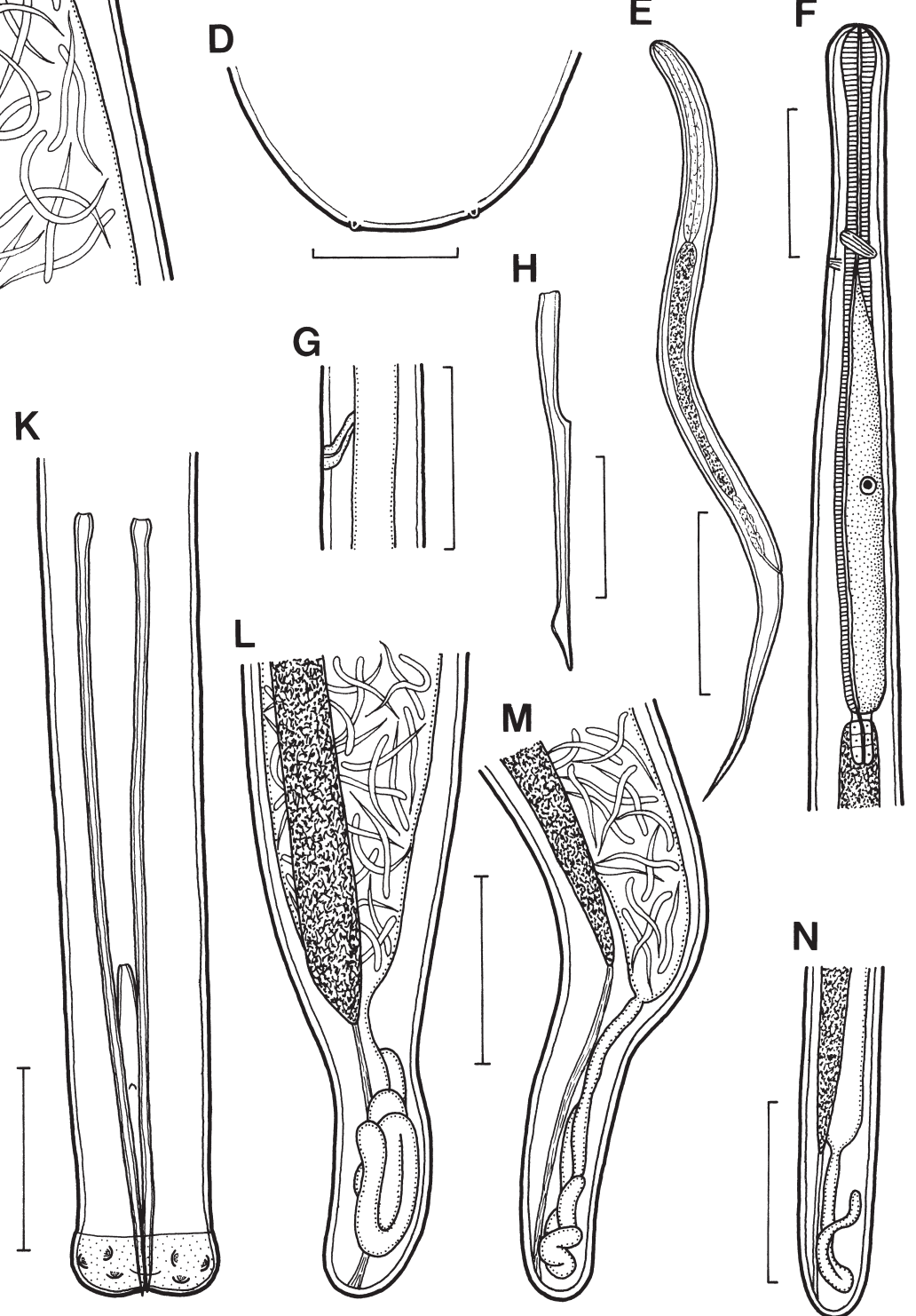

Fig. 4. Philometra tenuicauda sp. n. A - anterior end of gravid female, lateral view; $\mathbf{B}, \mathbf{C}$ - cephalic end of gravid female, lateral and apical views; D - caudal end of gravid female, dorsoventral view; $\mathbf{E}$ - larva from uterus, lateral view; $\mathbf{F}$ - anterior end of mature female, lateral view; $\mathbf{G}$ - region of vulva of mature female, lateral view; $\mathbf{H}$ - gubernaculum, lateral view; $\mathbf{I}$ - anterior end of male, lateral view; J, K - posterior end of male, lateral and ventral views; $\mathbf{L}, \mathbf{M}$ - posterior ends of two different gravid females, dorsolateral and lateral views; $\mathbf{N}$ - caudal end of mature female, lateral view. Scale bars: A $=300 \mu \mathrm{m} ; \mathrm{B}=200 \mu \mathrm{m} ; \mathrm{C}, \mathrm{H}=30 \mu \mathrm{m} ; \mathrm{D}-\mathrm{G}, \mathrm{I}$, $\mathrm{N}=100 \mu \mathrm{m} ; \mathrm{J}, \mathrm{K}=50 \mu \mathrm{m} ; \mathrm{L}, \mathrm{M}=500 \mu \mathrm{m}$. 
Seven gonad-infecting species of Philometra are known only by females, with mostly uniform morphology, whereas conspecific males have not yet been discovered. Since philometrids exhibit a fairly high degree of host specificity (Moravec 2006), these seven species can be distinguished from $P$. priacanthi only by their host types (Priacanthidae vs. Centrolophidae, Mugilidae, Scombridae, Sebastidae, Serranidae, Sparidae, Stromateidae, Synanceiidae) and geographical distribution. Philometra priacanthi is the first gonad-infecting species of Philometra described from the Priacanthidae; none of the above mentioned seven gonad-infecting species was reported from the region of the western South Pacific.

\section{Philometra tenuicauda sp. n.}

Figs. 4, 5

Male (1 specimen; holotype): Body filiform, whitish, $4.19 \mathrm{~mm}$ long, maximum width 63 , somewhat narrowed at region anterior of nerve ring; width of cephalic end 45, of caudal end 33. Cephalic end rounded, cephalic papillae indistinct in lateral view. Oesophagus 480 long, representing $11 \%$ of body length, somewhat inflated at anterior end; posterior part of muscular oesophagus overlapped by well-developed oesophageal gland with large cell nucleus located slightly anterior to middle of gland. Nerve ring and oesophageal nucleus 177 and 309, respectively, from anterior extremity (Fig. 4I). Excretory pore somewhat posterior to level of nerve ring, 219 from anterior end of body. Posterior end of body blunt, with broad, U-shaped lobular mound and with one pair of preanal, one pair of adanal and one pair of postanal very flat, hardly visible caudal papillae. Spicules slender, needle-like, with slightly expanded proximal and sharply pointed distal ends; right spicule slightly longer than left spicule (Fig. 4J, K). Length of right spicule 249, of left spicule 245; length ratio of spicules 1:1.02; length of right spicule representing $5.94 \%$ of body length. Gubernaculum narrow, 102 long, with approximately its proximal third somewhat dorsally bent; length of anterior bent part 36, representing $35 \%$ of entire gubernaculum length; distal end of gubernaculum appearing to be smooth, with distinct protuberance on dorsal side (Fig. 4H). Length ratio of gubernaculum and right spicule 1:2.44. Spicules and gubernaculum well sclerotized, orange-brown in colour.

Gravid female (2 specimens; measurements of allotype; those of paratype in parentheses): Body of fixed specimens light brown, with dark brown intestine visible through cuticle. Cuticle smooth. Body length 290 (335) $\mathrm{mm}$, maximum width 1,428 (966), maximum width/body length ratio 1:203 (1:347); posterior part of body narrower than anterior part. Body markedly narrowed at caudal region posterior to end of intestine; this narrowed part of body 775 (789) long, containing intestinal ligament and coiled posterior ovary (Fig. 4L, M). Cephalic end rounded, 381 (272) wide. Cephalic papillae very small, indistinct when viewed laterally. Oral aperture rather small, al-
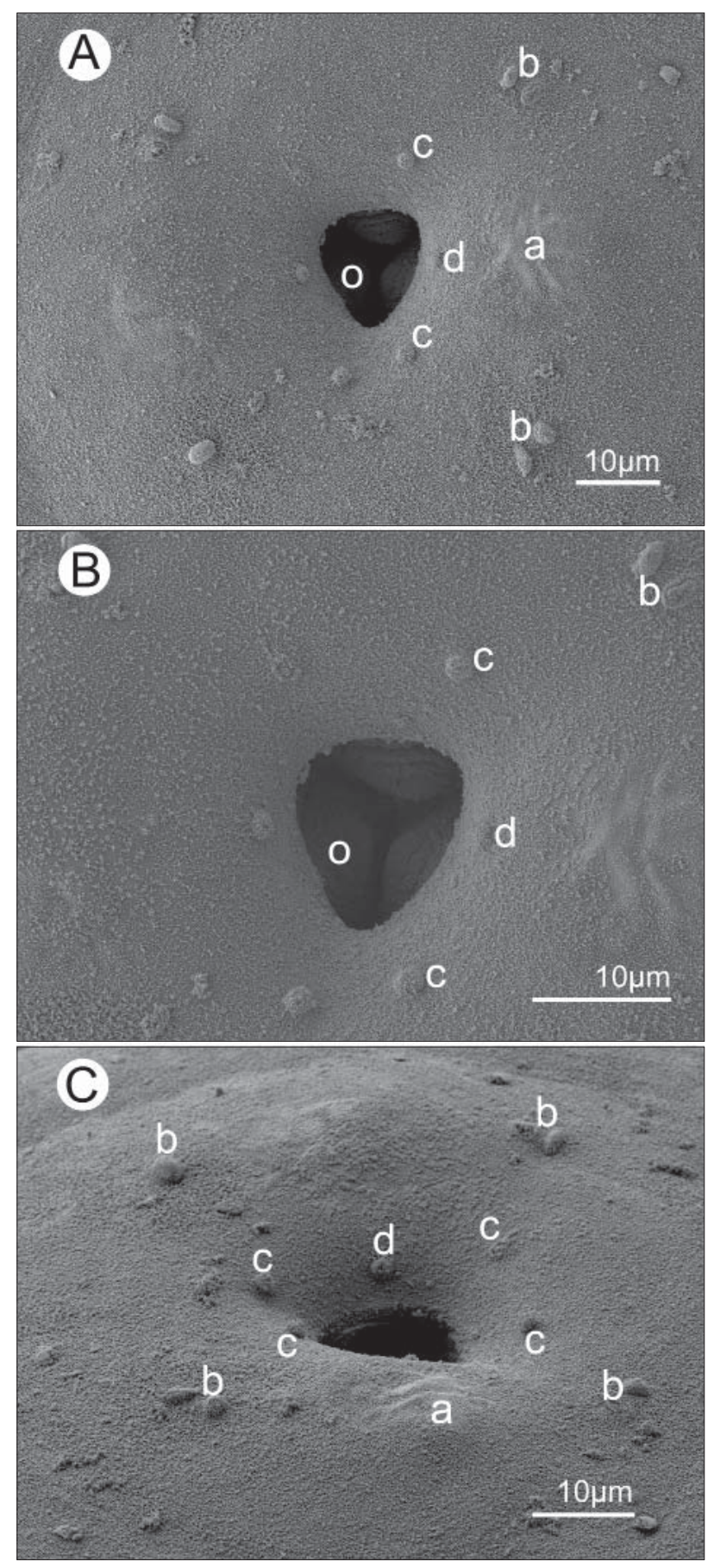

Fig. 5. Philometra tenuicauda sp. n., scanning electron micrographs of gravid female. A - cephalic end, apical view; $\mathbf{B}$ - region of oral aperture, apical view; $\mathbf{C}$ - cephalic end, sublateral view. Abbreviations: $\mathrm{a}-$ amphid; $\mathrm{b}$ - submedian pair of cephalic papillae of external circle; $\mathrm{c}$ - submedian papilla of internal circle; $d$ - lateral papilla of internal circle; o - mouth with three surfaces of oesophageal sectors at bottom.

most triangular, surrounded by 4 pairs of small papillae of external circle and 6 single papillae (2 lateral and 4 submedian) of internal circle; each pair of external papillae consisting of one rounded and one more elongate papilla 
(Figs. 4C, 5A-C). Bottom of mouth formed by flat surfaces of three oesophageal sectors. Anterior end of oesophagus somewhat bulbously inflated. Length of entire oesophagus including anterior inflation 1.41 (1.50) mm long, representing $0.5(0.5) \%$ of body length; bulbous inflation 109 (136) long and 122 (136) wide. Oesophageal gland well developed, opening into oesophagus just posterior to nerve ring; large cell nucleus located slightly anterior to middle of gland, 857 (966) from anterior extremity. Nerve ring 367 (354) from anterior end of body. Small ventriculus 41 (-) long and 109 (-) wide (Fig. 4A). Oesophagus opening into intestine through distinct valve. Intestine broad at anterior end; its posterior end narrow, attached by long ligament ventrally to body wall near caudal end; ligament 816 (734) long. Vulva and anus absent. Ovaries reflected, situated near body ends. Uterus occupying most space of body, filled with numerous larvae; anteriorly uterus extending nearly to level of nerve ring, posteriorly to end of intestine. Larvae $(n=5)$ from uterus 438-447 $(-)$ long, maximum width 15-18 (-), length of oesophagus $132-135$ (30-31\% of body length) (-), of sharply pointed tail 114-129 (26-29\%) (-); intestine of larvae granular, dark brown (Fig. 4E). Caudal end rounded, with two very small lateral papilla-like projections (Fig. 4D).

Mature female (3 specimens): Body filiform, lightcoloured, 3.77-4.46 mm long, maximum width 54-66. Cephalic and caudal ends 39-42 and 33-36, respectively, wide. Cephalic end rounded, cephalic papillae indistinct. Entire oesophagus 516-540 long, representing 12-14\% of body length, and 30-36 wide; its anterior inflation 45-48 long and 24-30 wide. Oesophageal gland well developed (Fig. 4F). Small ventriculus 9-18 long, 21-27 wide. Nerve ring and oesophageal cell nucleus 159-165 and 303-357, respectively, from anterior extremity. Excretory pore 183-186 from anterior end of body. Intestinal ligament 69-90 long. Vulva covered with plug situated $2.71-2.79 \mathrm{~mm}$ from anterior extremity (at $61-72 \%$ of body length); vagina directed anteriorly from vulva (Fig. 4G). Uterus tubular, empty. Ovaries near ends of body. Caudal end rounded, without any projections (Fig. 4N).

Type host: Silverstripe blaasop Lagocephalus sceleratus (Tetraodontidae, Tetraodontiformes).

Site of infection: Ovary.

Type locality: Off Nouméa, New Caledonia, South Pacific.

Prevale n c e : $2 / 4$ for fish collected during hot season (30 October 2007); 0/4 for fish collected in cold season, although with well developed ovaries (30 August 2008).

Note about fish: Fish examined were small (fork length $160-178 \mathrm{~mm}$, weight $57-85 \mathrm{~g}$ ) in comparison to the maximum size of this species $(1,100 \mathrm{~mm}, 7 \mathrm{~kg}$; Froese and Pauly 2009)

Deposition of types: Holotype (male) (JNC 2360), allotype (gravid female) (JNC 2360) and 3 paratypes (mature females) (JNC 2361) in Muséum National d'Histoire Naturelle, Paris; 1 paratype (gravid female) in Institute of Pa- rasitology, Biology Centre, ASCR, České Budějovice (Cat. No. N-925).

Etymology: The specific name is composed of two Latin words, tenuis (=thin, slender) and cauda (=tail), and relates to a characteristic feature of this species, i.e., a conspicuously narrowed caudal end of gravid female.

Remarks. Of 27 presently recognized gonad-infecting species of Philometra (see Moravec et al. 2009), seven are known only by females, whereas conspecific males have not yet been described. From these seven species, as well as from all other gonad-infecting species of Philometra, $P$. tenuicauda differs mainly in having a conspicuously narrowed caudal end of gravid females. The new species can be also differentiated from the other seven by some morphological features (e.g., the presence of an anterior oesophageal inflation and caudal projections, or the relative length of the oesophagus to the body length), different host families (Centrolophidae, Platycephalidae, Scombridae, Sebastidae, Serranidae, Sparidae), and different geographical regions (Mediterranean Sea or the Pacific Ocean adjacent to Japan or Peru) (see the key in Moravec et al. 2008a).

From the remaining gonad-infecting Philometra spp. for which males are known, including $P$. priacanthi newly described in this paper, $P$. tenuicauda can be easily distinguished by its very long spicules. Only three species, P. cyanopodi, P. jordanoi (López-Neyra, 1951) and P. margolisi Moravec, Vidal-Martínez et AguirreMacedo, 1995, have spicules longer than $200 \mu \mathrm{m}$, in all other species they are distinctly shorter. However, the spicules of $P$. margolisi (432-468) are nearly twice as long as those of $P$. tenuicauda. The spicule lengths are similar only in $P$. cyanopodi (183-228) and $P$. jordanoi (260-265) (see Merella et al. 2004, Moravec and Justine 2008), both described from gonads of Epinephelus spp. (Serranidae, Perciformes) in the South Pacific (off New Caledonia) and the Mediterranean Sea, respectively. However, the distal end of the gubernaculum of these two species lacks a dorsal protuberance, characteristic of P. tenuicauda; moreover, dorsal lamella-like structures on the gubernaculum of $P$. cyanopodi were not observed in the new species.

Philometra tenuicauda is the first known gonad-infecting species of this genus parasitizing tetraodontiform fishes. Rasheed (1965) reported female nematodes collected from testes of Arothron hispidus (Linnaeus) and "Tetradon" (=? Arothron) sp. from Australia, which she provisionally identified as Philometra pellucida (Jägerskiöld, 1893). However, it was evident misidentification (Moravec 2006).

Another philometrid, Philometra lagocephali, has recently been described from a female specimen found in the abdominal cavity of the same host species (L. sceleratus) as $P$. tenuicauda off New Caledonia (Moravec and Justine 2008). It is well known that individual species 
A

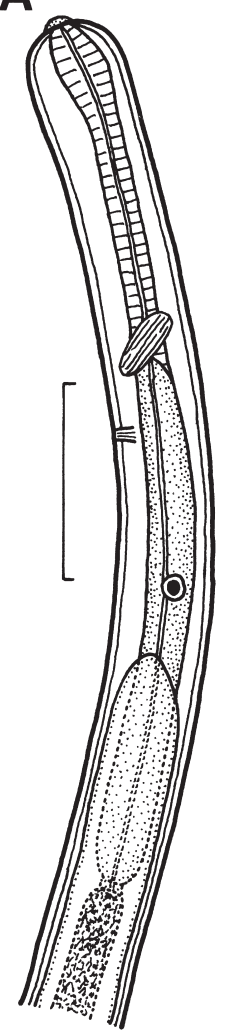

B
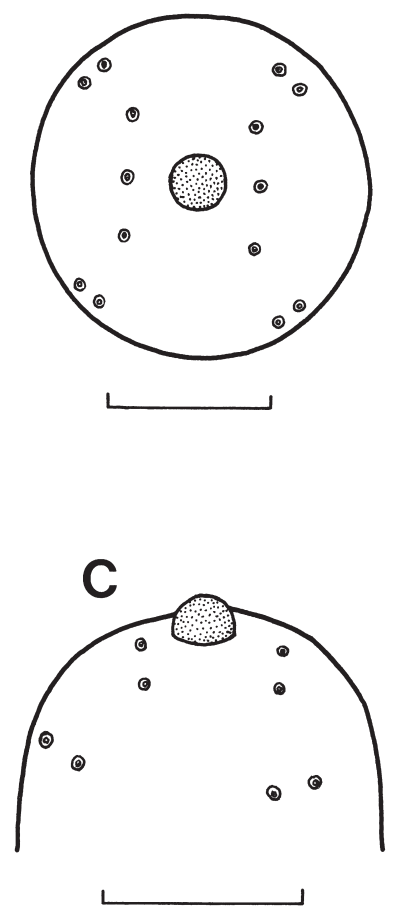

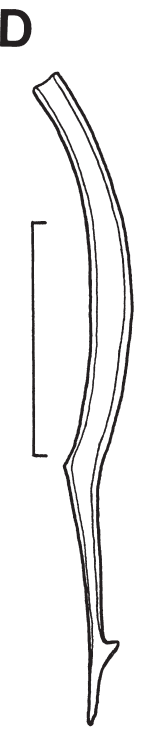

E

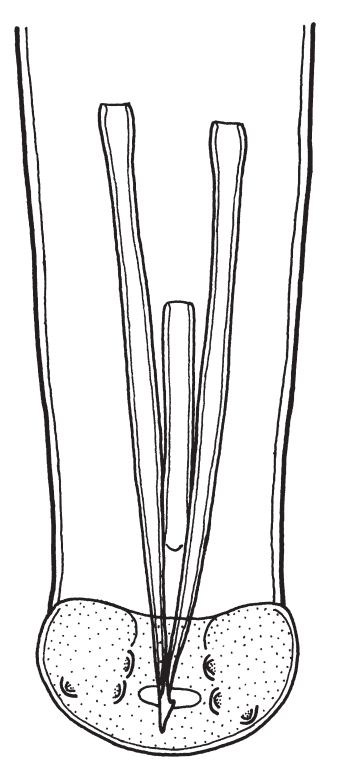

$\mathbf{F}$

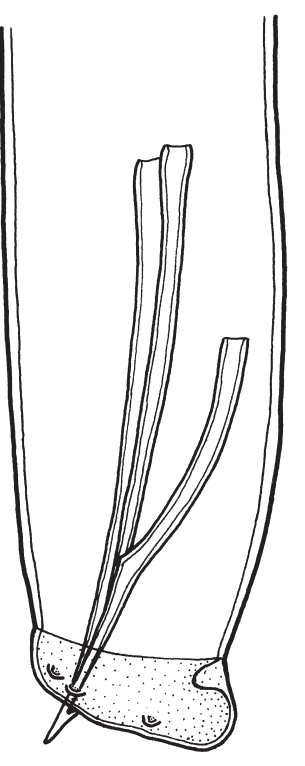

Fig. 6. Philometra dentigubernaculata sp. n., male. A - anterior end of body, lateral view; B, $\mathbf{C}$ - cephalic end, apical and dorsoventral views; D - gubernaculum, lateral view; $\mathbf{E}, \mathbf{F}$ - posterior end, ventral and lateral views. Scale bars: $\mathrm{A}=100 \mu \mathrm{m} ; \mathrm{B}, \mathrm{C}=20 \mu \mathrm{m}$; $\mathrm{D}=30 \mu \mathrm{m} ; \mathrm{E}, \mathrm{F}=50 \mu \mathrm{m}$.

of Philometra are characterized, in addition to morphological features, by their location in the host, particularly that of gravid females (Moravec 1978, 2004). Philometra lagocephali can be easily distinguished from the new species also morphologically: its gravid female is much shorter (53 vs. $290-335 \mathrm{~mm}$ ), the maximum width/body length is very different (1:21 vs. 1:203-335), the length of oesophagus represents $2 \%$ (vs. $0.5 \%$ ) of body length, and the caudal end is broad (vs. conspicuously narrowed), without any projections (vs. with two small projections).

\section{Species from oculo-orbits}

\section{Philometra dentigubernaculata sp. n. Figs. 6, 7}

Male (2 specimens; holotype; measurements of paratype in parentheses): Body filiform, whitish, 4.99 (4.65) $\mathrm{mm}$ long, maximum width at middle $66(60)$. Width of cephalic end 54 (51), of caudal end 45 (36). Cuticle smooth. Oral aperture of both available specimens overlapped by ball-shaped formation (probably prolapsed part of oesophagus densely covered with bacteria) (Fig. 7A-C). Minute cephalic papillae arranged in two circles: external circle formed by 4 submedian pairs of papillae, internal circle by 4 submedian and 2 lateral (Figs. 6B, 7A).
Oesophagus 498 (366) long, forming 10 (8)\% of body length, somewhat inflated at anterior end; anterior inflation $45(-)$ long and $30(-)$ wide; posterior part of muscular oesophagus overlapped by well-developed oesophageal gland with large cell nucleus in middle. Nerve ring and oesophageal nucleus 174 (174) and 315 (294), respectively, from anterior extremity. Excretory pore 246 (201) from anterior end of body. Testis not reaching anteriorly level of oesophageal nucleus (Fig. 6A). Posterior end of body somewhat narrowed, blunt, with lobular, U-shaped mound; 1 pair of preanal, 1 pair of adanal, and 1 pair of postanal, very flat and hardly visible caudal papillae present (Figs. 6E, F, 7E, F). Spicules slender, needle-like, with somewhat expanded proximal and sharply pointed distal ends; right spicule slightly longer than left spicule (Fig. 6E, F). Length of right spicule 114 (105), of left spicule 111 (99); length ratio of spicules 1:1.03 (1:1.06); length of right spicule representing 2.28 (2.26)\% of body length. Gubernaculum narrow, smooth, 84 (90) long, with approximately its proximal two thirds somewhat dorsally bent; length of anterior bent part 48 (54), representing 57 (60)\% of entire gubernaculum length; distal end of gubernaculum with distinct reflected dorsal barb (Figs. 6D, 7D). Length ratio of gubernaculum and right 


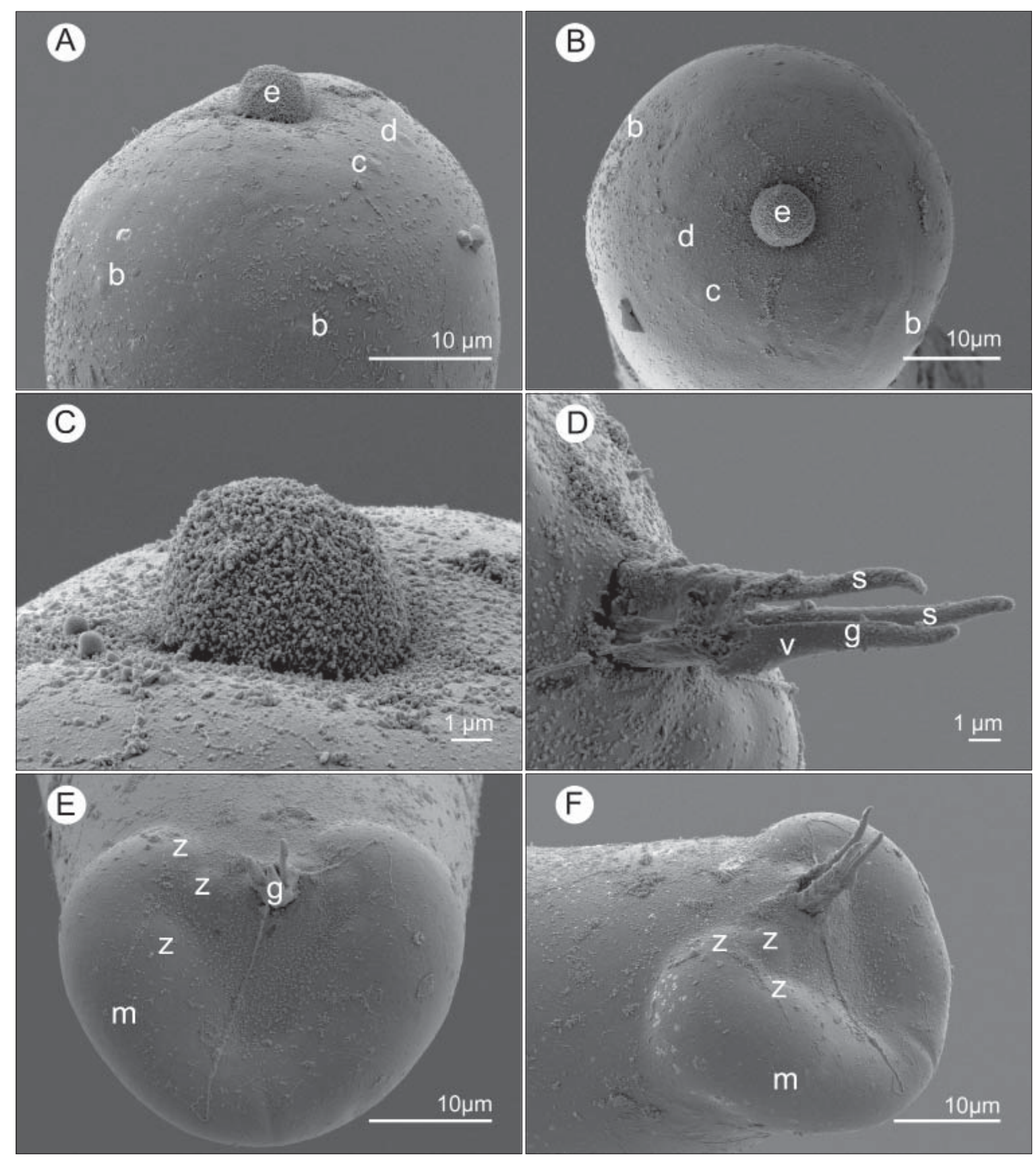

Fig. 7. Philometra dentigubernaculata sp. n., scanning electron micrographs of male. A, $\mathbf{B}$ - cephalic end, dorsoventral and apical views; C - ball-like structure at mouth; D - region of cloacal opening with partly extruded spicules and gubernaculum, lateral view; E, F - caudal end, apical and sublateral views. Abbreviations: b - submedian cephalic papilla of external circle; $\mathrm{c}$ - submedian cephalic papilla of internal circle; $\mathrm{d}$ - lateral cephalic papilla of internal circle; $\mathrm{e}$ - ball-like structure at mouth; $\mathrm{g}$ - gubernaculum; $\mathrm{m}$ - U-shaped caudal mound; $\mathrm{s}$ - spicule; $\mathrm{v}$ - dorsal reflected barb on distal gubernaculum end; $\mathrm{z}$ - caudal papilla.

spicule 1:1.36 (1:1.17). Spicules and gubernaculum well sclerotized; spicules and posterior part of gubernaculum orange-brown, anterior part of gubernaculum colourless.

\section{Female: Unknown.}

Type host: Hound needlefish Tylosurus crocodilus (Belonidae, Beloniformes).

Site of infection: Oculo-orbit (eye grease).

Typ e loc ality: South Pacific, off Nouméa, New Caledonia (collected 26 September 2006).

Prevale n ce: $1 / 1$, fish examined $880 \mathrm{~mm}$ in fork length.

Deposition of type: Holotype (male) in Muséum National d'Histoire Naturelle, Paris (JNC 1968).

Etymology: The specific name is composed of two Latin words, dens (= tooth) and gubernaculum (= accessory piece, gubernaculum), and relates to a characteristic feature of this species, i.e., the presence of a barb (tooth) on the gubernaculum. 
Remarks. To date, five species of Philometra and four of Philometroides Yamaguti, 1935 are known to be parasites of the oculo-orbits of fishes (Moravec 2006, Moravec et al. 2008c); both these genera differ from each other by the absence/presence of cuticular ornamentations on the body surface of large females, whereas the males of both genera have smooth cuticle and are thus indistinguishable. However, of these species, the following five are parasites of freshwater fishes in East Asia (Japan, Russia) or North America (USA): Philometra orbitalensis Moravec, Crosby, de Buron, González-Solís et Roumillat, 2008, P. parasiluri Yamaguti, 1935, Philometroides anguillae (Ishii, 1916), P. moraveci Vismanis et Yunchis, 1994 and P. wellborni Moravec, Crosby, de Buron, González-Solís et Roumillat, 2008. The males were described only for $P$. moraveci and P. wellborni (see Ermolenko 1984, Moravec 2006, Moravec et al. 2008c); it can be remarked that both these species are characterized by the gubernaculum provided with a dorsal reflected barb as in $P$. dentigubernaculata.

Only four species are known from oculo-orbits of marine fishes: Philometra balistii Rasheed, 1963 from Balistes sp. (type host) and Abalistes stellaris (Bloch et Schneider) (both Balistidae, Tetraodontiformes) in the Indian Ocean, Red and South China Seas (Rasheed 1963, Parukhin 1971, 1989), Philometra ocularis from Epinephelus spp. and Variola louti (Forsskål) (both Serranidae, Perciformes) off Japan and New Caledonia (Moravec et al. 2002, Moravec and Justine 2005, 2008), Philometra salgadoi Vidal-Martínez, Aguirre-Macedo et Moravec, 1995 from Epinephelus morio in the Gulf of Mexico (Vidal-Martínez et al. 1995, Moravec et al. 1997, 2001), and Philometroides oveni Parukhin, 1975 from Serranus hepatus (Linnaeus) in the Mediterranean Sea (Parukhin 1975). Of them, the males were described only in P. salgadoi (see Moravec et al. 2001), differing from $P$. dentigubernaculata mainly in the absence of a reflected dorsal barb on the gubernaculum. Remaining four species can be distinguished only by different host superfamilies (Beloniformes vs. Perciformes or Tetraodontiformes) and different geographical regions.

In addition to the new species, Tylosurus crocodilus was previously reported as the host of Philometra tylosuri Moravec et Ali, 2005, a species described solely from females found in the musculature and subcutaneous tissue of this fish in the Persian Gulf, southern Iraq (Moravec and Ali 2005). Other two species, Philometra kohnae Moravec et Rohde, 1992 and P. lomi Moravec et Rohde, 1992, were described from females collected from subcutaneous tissues of the congeneric host Tylosurus gavialoides (Castelnau) off the Pacific coast of eastern Australia (New South Wales) (Moravec and Rohde 1992). Unfortunately, males of these three species remain unknown, so that their comparison with $P$. dentigubernaculata is so far impossible. Even though it cannot be excluded that

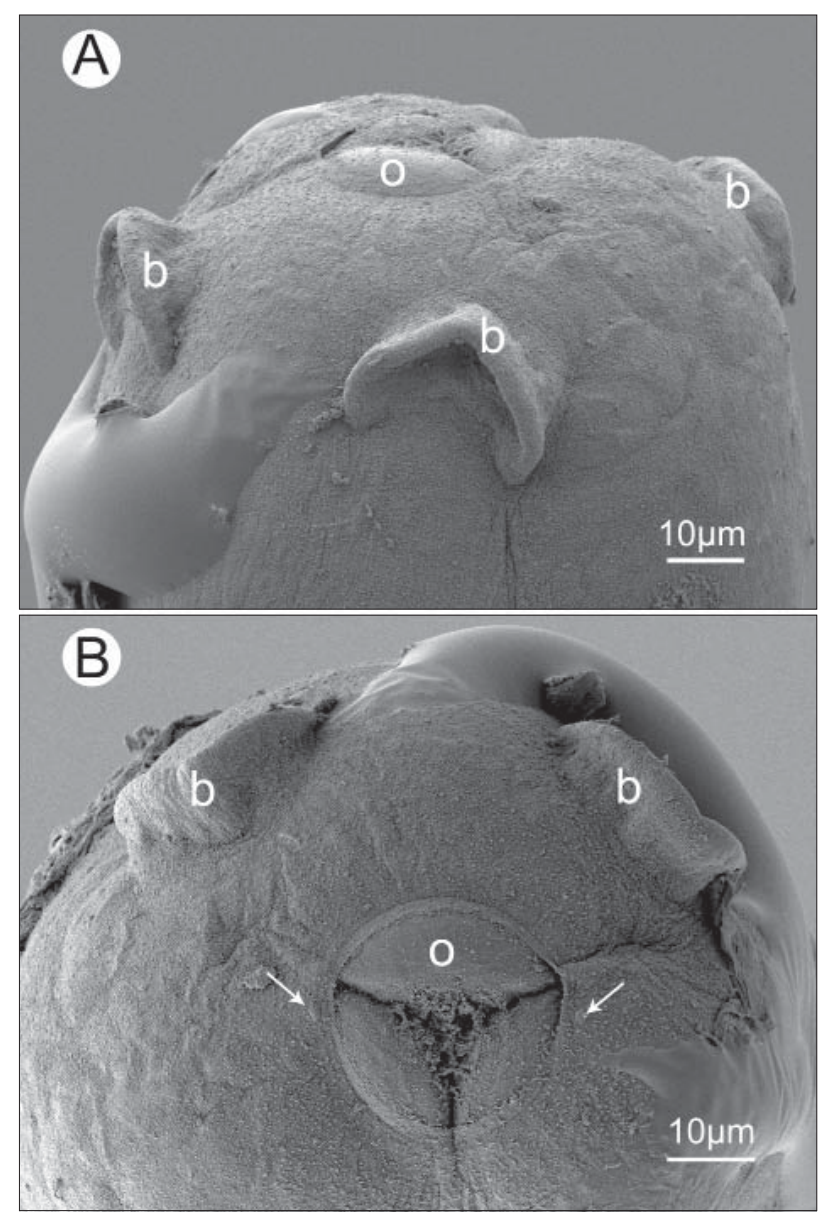

Fig. 8. Philometra ocularis Moravec, Ogawa, Suzuki, Miyzaki et Donai, 2002, scanning electron micrographs of gravid female. A - cephalic end, dorsal view; B - cephalic end, apical view (arrows indicate lateral cephalic papillae of internal circle). Abbreviations: $\mathrm{b}$ - submedian crescent-shaped cephalic papilla of external circle; o - mouth with three surfaces of oesophageal sectors.

the males of the present material belong to one of these species, taking into account the high degree of site specificity in philometrids, we consider it reasonable to establish a new species to accommodate them. Certainly, further studies of $P$. dentigubernaculata are needed.

Philometra ocularis Moravec, Ogawa, Suzuki, Miyazaki et Donai, 2002

Fig. 8

Gravid female ( 3 body fragments of 1 specimen): Total length of body fragments $22.71 \mathrm{~mm}$, maximum width 394; width of cephalic end 109. Height of external cephalic papillae 12 (Fig. 8A, B). Entire oesophagus 1.34 mm long, maximum width 177; anterior bulbous inflation 117 long, 102 wide. Nerve ring and oesophageal cell nucleus 367 and 1,292, respectively from anterior extremity. Larvae from uterus not measured.

Host: Areolate grouper Epinephelus areolatus (Serranidae, Perciformes). 
Site of infection: Oculo-orbit.

L o c a lity: Off Nouméa, New Caledonia, South Pacific.

Prevalence: 1/3. Infected fish specimen, 19 October 2006, fork length $220 \mathrm{~mm}$.

Deposition of voucher specimen: Muséum National d'Histoire Naturelle, Paris (JNC 1956).

Remarks. This species was described from females from oculo-orbits of Epinephelus septemfasciatus (Thunberg) off Japan (Moravec et al. 2002) and later it was recorded (again only females) from five other species of serranid fishes, Epinephelus areolatus (Forsskål), E. coioides (Hamilton), E. cyanopodus (Richardson), E. rivulatus (Valenciennes) and Variola louti (Forsskål), off New Caledonia (Moravec and Justine 2005, 2008). The conspecific male remains unknown.

Guyanemidae Petter, 1974

Travassosneminae Moravec, 2006

\section{Ichthyofilaria novaecaledoniensis $\mathrm{sp} . \mathrm{n}$.}

Fig. 9

Female (1 subgravid specimen; holotype): Body filiform, yellowish, $17.29 \mathrm{~mm}$ long, maximum width near middle of body 272, tapering at both ends. Cuticle smooth. Anterior end bluntly rounded (Fig. 9A). Cephalic papillae small, indistinct in lateral view. Muscular oesophagus narrow, 246 long (1.5\% of body length), almost cylindrical, without anterior inflation; glandular oesophagus narrower, very short, 15 long, provided with free appendix 233 long and 24 wide (Fig. 9A). Oesophagus opening into intestine through valve. Nerve ring encircling muscular oesophagus 75 from anterior extremity; excretory pore just anterior to glandular oesophagus. Intestine light-coloured, its anterior part forming several spiral coils, then straight. Intestine ending blindly, being attached ventrally to body wall by short, fine ligament at distance of 213 from posterior extremity (Fig. 9C, D). Amphidelphic. Vulva and vagina not found. Uterus occupying major part of body, being filled with huge number of developing embryos; no fully developed larvae present. Anterior ovary markedly reduced, located at region of glandular oesophageal appendix (Fig. 9A), posterior ovary considerably long (Fig. 9C). Caudal end conical, with small terminal cuticular point 3 long (Fig. 9D).

Type host: Lemon ghost flathead, Hoplichthys citrinus (Hoplichthyidae, Scorpaeniformes).

Site of infection: Flesh near gills.

Type locality: CHONDRICAL deep-sea cruise, Station $\mathrm{CH} 3$, off Banc de Coëtlogon (22 $\left.17^{\prime} 42 \mathrm{~S}, 167^{\circ} 12^{\prime} 40 \mathrm{E}\right)$, off New Caledonia, depth 385-401 m, 30 January 2002.

Intensity: A single fresh fish specimen from the $\mathrm{CHON}$ DRICAL cruise was examined and was positive. A total of about 100 frozen specimens from the deep-sea cruises around New Caledonia EBISCO (October 2005, Chesterfield Islands) and TERRASSE (October 2008, Norfolk Ridge and other localities) were negative.
Deposition of type: Holotype in Muséum National d'Histoire Naturelle, Paris (JN 35A).

Etymology: Specific name of this nematode relates to the country of its origin, i.e., New Caledonia.

Remarks. The general morphology of this nematode, in particular the structure of the oesophagus, the shape of the caudal end and the development of ovaries, as well as the location in the host, suggest that it belongs to Ichthyofilaria. At present, the genus contains five species, all parasitic in the abdominal cavity or viscera of marine fishes: I. argentinensis Incorvaia, 1999, I. bergensis (Wülker, 1930), I. canadensis Appy, Anderson et Khan, 1985, I. dasycotti Yamaguti, 1935 and I. japonica Moravec et Nagasawa, 1985 (see Moravec 2006). Ichthyofilaria argentinensis differs from the present specimen in having the glandular appendix 4-6 times as long as the oesophagus (vs. approximately equally long as oesophagus), I. bergensis in the much longer body of females (41-63 vs. $17.3 \mathrm{~mm}$ ), and I. canadensis in having the glandular appendix much shorter than the oesophagus (Appy et al. 1985, Køie 1993, Timi et al. 2001); all these three species are parasites either of Gadiformes or Perciformes in the Atlantic Ocean.

The two remaining species, I. dasycotti and I. japoni$\mathrm{ca}$, are parasites of Scorpaeniformes in the North Pacific (Japan), but the former differs from the specimen of the present material mainly in possessing a very short glandular appendix approximately as long as the glandular oesophagus proper (vs. appendix approximately as long as the entire oesophagus) and in having much longer females (34-38 vs. $17.3 \mathrm{~mm}$ ), whereas the latter is easily distinguishable by the presence of four conspicuously large lobe-like cephalic projections (Yamaguti 1935, Moravec and Nagasawa 1985); I. dasycotti and I. japonica also differ in the families of their fish hosts (Psychrolutidae and Sebastidae, respectively vs. Hoplichthyidae). Therefore, the present specimen is considered to represent a new species, I. novaecaledoniensis. The authors are aware of the fact that it is being described from a single specimen, a procedure that cannot be generally recommended; however, in this case, the new species appears to be well established and, therefore, they consider it more reasonable and useful to give it a specific name rather than to report it only as Ichthyofilaria sp.

The only other nematodes reported from this deep-sea fish are the cystidicolid Ascarophis richeri Moravec et Justine, 2007 and anisakid larvae (Moravec and Justine 2007).

Acknowledgements. Eva Řehulková (Brno), and several students, including Aude Sigura, Cyndie Dupoux and Isabelle Mary participated in the fishing operations and parasitological survey. Annie Petter (MNHN) helped for an early triage of the material. Sam Tereua, Miguel Clarque and Napoléon Colombani, captains of the NO "Coris" provided safe navigation. Gérard Mou-Tham, Paco Bustamante and Michel Warnau spear-fished several fish. 

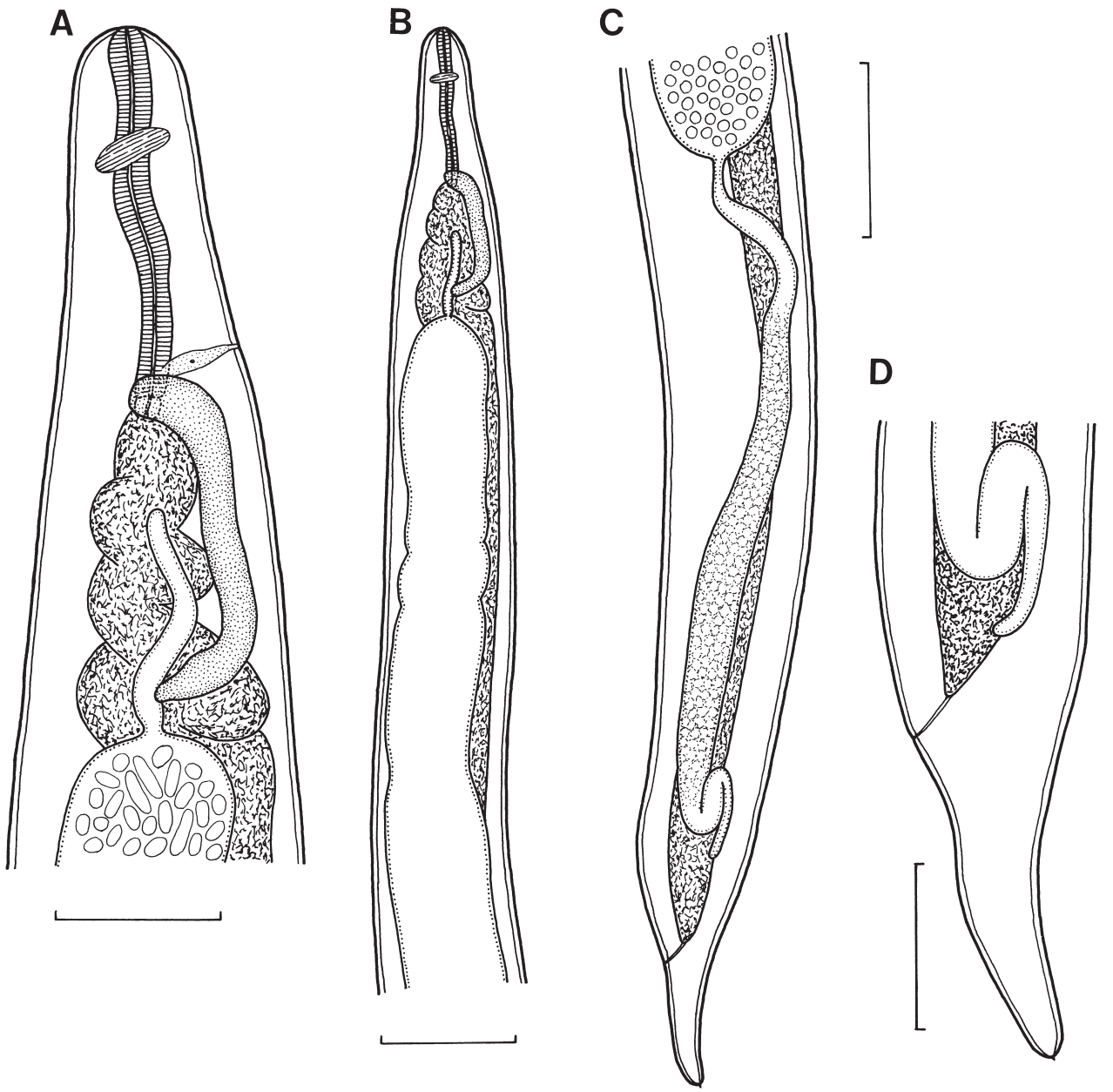

Fig. 9. Ichthyofilaria novaecaledoniensis sp. n., female. A - anterior end of body, lateral view; B, C - anterior and posterior parts of body, lateral views; D - caudal end, lateral view. Scale bars: A, D = $100 \mu \mathrm{m} ; \mathrm{B}, \mathrm{C}=200 \mu \mathrm{m}$.

Gérard Mou-Tham and Michel Kulbicki (IRD) provided identifications. Fishes from the deep-sea cruises CHONDRICAL, EBISCO and TERRASSE were provided, respectively, by Bernard Séret, Bertrand Richer de Forges and Sarah Samadi. Angelo di Matteo (IRD) provided technical help. Ronald Fricke (Staatliches Museum für Naturkunde, Stuttgart, Germany) identified the Tylosurus crocodilus (from specimen) and certain Epinephelus specimens (from photographs). Thanks are due to the staff of the
Laboratory of Electron Microscopy of the Institute of Parasitology, Biology Centre of the ASCR, in České Budějovice for their technical assistance and Blanka Škoríková and Irena Husáková from the Department of Helminthology of the same Institute for their help with the preparation of illustrations. This study was partly supported by grant No. 524/06/0170 from the Grant Agency of the Czech Republic and by the research projects of the Institute of Parasitology, ASCR (Z60220518 and LC522).

\section{REFERENCES}

Allsop D.J., West S.A. 2003: Constant relative age and size at sex change for sequentially hermaphroditic fish. J. Evol. Biol. 16: 921-929.

Appy R.G., Anderson R.C., Khan R.A. 1985: Ichthyofilaria canadensis n. sp. (Nematoda: Dracunculoidea) from eelpouts (Lycodes spp.). Can. J. Zool. 63: 1590-1592.

Clarke L.M., Dove A.D.M., Conover D.O. 2006: Prevalence, intensity, and effect of a nematode (Philometra saltatrix) in the ovaries of bluefish (Pomatomus saltatrix). Fish. Bull. 104: $118-124$.

ERmolenko A.V. 1984: [On the systematic status and biology of Philometra parasiluri Yamaguti, 1935 (Nematoda, Philometridae).] In: Yu.L. Mamaev, V.A. Dvoryadkin and A.S. Eroshenko
(Eds.), Parasites of Animals and Plants. Far-Eastern Scientific Center of the USSR Acad. Sci., Vladivostok, pp. 78-81. (In Russian.)

Froese R., Pauly D. (Eds.) 2009: FishBase. World Wide Web electronic publication, www.fishbase.org, 3/2009.

KøIE M. 1993: Nematode parasites in teleosts from 0 to $1540 \mathrm{~m}$ depth off the Faroe Islands (the North Atlantic). Ophelia 38: 217-243.

Merella P., Reñones O., Garippa G. 2004: Finding of one male Philometra lateolabracis (Nematoda: Philometridae) parasite on the dusky grouper Epinephelus marginatus (Osteichthyes: Serranidae) in the western Mediterranean. Parassitologia 46 (Suppl. 1): 158 . 
Moravec F. 1978: Redescription of the nematode Philometra obturans (Prenant, 1886) with a key to the philometrid nematodes parasitic in European freshwater fishes. Folia Parasitol. 25: $115-124$

Moravec F. 2004: Some aspects of the taxonomy and biology of dracunculoid nematodes parasitic in fishes: a review. Folia Parasitol. 51: 1-13.

Moravec F. 2006: Dracunculoid and Anguillicoloid Nematodes Parasitic in Vertebrates. Academia, Prague, 634 pp.

Moravec F., Ali A.H. 2005: Two new species of Philometra (Nematoda: Philometridae) from needlefishes (Belonidae) in Iraq, with a key to Philometra spp. parasitic in the host's subcutaneous tissue, fins and musculature. Folia Parasitol. 52: 267-273.

Moravec F., Crosby M.D., de Buron I., González-Solís D., Roumillat W.A. 2008c: Three new species of philometrids (Nematoda: Philometridae) from centrarchid fishes in the USA. J. Parasitol. 94: 1103-1113.

Moravec F., de Buron I., Baker T.G., González-Solís D. 2008a: Some gonad-infecting species of Philometra (Nematoda, Philometridae) from offshore fishes of South Carolina and Georgia, USA, including Philometra charlestonensis sp. nov. from the scamp Mycteroperca phenax. Acta Parasitol. 53: 382-391.

Moravec F., Fajer-Avila E.J., Bakenhaster M. 2009: Philometra floridensis sp. n. (Nematoda: Philometridae) from the ovary of red drum Sciaenops ocellatus (Osteichthyes: Sciaenidae) off Florida, USA. J. Helminthol. (In press.)

Moravec F., Genc E. 2004: Redescription of three Philometra spp. (Nematoda, Philometridae) from the gonads of marine perciform fishes of Iskenderun Bay (North-East Mediterranean), Turkey. Acta Parasitol. 49: 31-40.

Moravec F., Justine J.-L. 2005: Two species of Philometra (Nematoda, Philometridae) from serranid fishes off New Caledonia. Acta Parasitol. 50: 323-331.

Moravec F., Justine J.-L. 2007: A new species of Ascarophis (Nematoda, Cystidicolidae) from the stomach of the marine scorpaeniform fish Hoplichthys citrinus from a seamount off the Chesterfield Islands, New Caledonia. Acta Parasitol. 52: 238-246.

Moravec F., Justine J.-L. 2008: Some philometrid nematodes (Philometridae), including four new species of Philometra, from marine fishes off New Caledonia. Acta Parasitol. 53: 369-381.

Moravec F., Magi M., Macchioni F. 2008b: Redescription of the gonad-infecting nematode Philometra saltatrix Ramachandran, 1973 (Philometridae) based on specimens from the type host Pomatomus saltatrix (L.) (Osteichthyes) from the Tuscan Sea, Italy. Folia Parasitol. 55: 219-223.

Moravec F., Nagasawa K. 1985: Ichthyofilaria japonica sp. n. (Philometridae) and some other nematodes from marine fishes from Hokkaido, Japan. Acta Soc. Zool. Bohemoslov. 49: 211223.

Moravec F., Ogawa K., Suzuki M., Miyazaki K., Donai H. 2002: On two species of Philometra (Nematoda, Philometridae) from the serranid fish Epinephelus septemfasciatus in Japan. Acta Parasitol. 47: 34-40.

Moravec F., Prista N., Costa M.J. 2007: Meagre Argyrosomus regius (Osteichthyes) as host of a gonad-infecting species of
Philometra (Nematoda: Philometridae) off the Atlantic coast of Portugal. Dis. Aquat. Org. 78: 83-86.

Moravec F., Rohde K. 1992: Three species of nematodes of the superfamily Dracunculoidea from Australian fishes. Acta Soc. Zool. Bohemoslov. 56: 187-195.

Moravec F., Salgado-Maldonado G. 2007: A new species of Philometra (Nematoda, Philometridae) from the gonads of the rock hind Epinephelus adscensionis (Osteichthyes) from the southern Gulf of Mexico. Acta Parasitol. 52: 376-381.

Moravec F., Vidal-Martínez V.M., Aguirre-Macedo M.L., GonzÁlez-Solís D. 2001: First description of the male and redescription of the female of Philometra salgadoi Vidal-Martínez et al., 1995 (Nematoda: Philometridae) from the ocular cavity of the marine fish Epinephelus morio in Mexico. Parasitol. Res. 87: 526-529.

Moravec F., Vidal-Martínez V.M., Vargas-Vázquez J., VivasRodríguez C., González-Solís D., Mendoza-Franco E., SimÁ-Alvárez R., Güemez-Ricalde J. 1997: Helminth parasites of Epinephelus morio (Pisces: Serranidae) of the Yucatan Peninsula, southeastern Mexico. Folia Parasitol. 44: 255-266.

PARUKhin A.M. 1971: [Nematodes from fishes of the Red Sea and Indian Ocean.] Sbor. "Voprosy Ekologii Ryb Yuzhnykh Morey", Biologiya Morya 23. Naukova Dumka, Kiev, pp. 177-193. (In Russian.)

Parukhin A.M. 1975: Philometroides oveni sp. n., a parasite of the sea perch Paracanthopristis hepatus. Zool. Zh. 54: 312-314. (In Russian, Engl. summary.)

PARUKhin A.M. 1989: [Parasitic worms of benthic fishes of the southern seas.] Naukova Dumka, Kiev, 154 pp. (In Russian.)

Quiazon K.M.A, Yoshinaga T., Ogawa K. 2008a: Taxonomical study into two new species of Philometra (Nematoda: Philometridae) previously identified as Philometra lateolabracis (Yamaguti, 1935). Folia Parasitol. 55: 29-41.

Quiazon K.M.A., Yoshinaga T., Ogawa K. 2008b: Philometra sawara $\mathrm{sp}$. $\mathrm{n}$. and a redescription of Philometra sciaenae Yamaguti, 1941 and Philometra nemipteri Luo, 2001 (Nematoda: Philometridae): a morphological and molecular approach. Folia Parasitol. 55: 277-290.

Rasheed S. 1963: A revision of the genus Philometra Costa, 1845. J. Helminthol. 37: 89-130.

RASHEED S. 1965: Additional notes on the family Philometridae Baylis and Daubney, 1926. J. Helminthol. 39: 349-362.

Sakaguchi S., Yamagata Y., Sako H. 1987: Reidentification of Philometra parasitic on the Red Sea bream. Bull. Natl. Res. Inst. Aquacult. 12: 69-72. (In Japanese, Engl. summary.)

Timi J.T., Navone G.T., Sardella N.H. 2001: Redescription of Ichthyofilaria argentinensis Incorvaia, 1999 (Nematoda: Philometridae) parasite of Merluccius hubbsi (Pisces: Merlucciidae) from Argentina. Folia Parasitol. 48: 139-142.

Vidal-Martínez V.M., Aguirre-Macedo L., Moravec F., 1995 Philometra (Ranjhinema) salgadoi n. sp. (Nematoda: Philometridae) from the ocular cavity of the red grouper Epinephelus morio (Pisces: Serranidae) from the Yucatan Peninsula, Mexico. J. Parasitol. 81: 763-766.

Yamaguti S. 1935: Studies on the helminth fauna of Japan. Part 9. Nematodes of fishes, 1. Jpn. J. Zool. 6: 337-386. 